\title{
Measurement of nurses' workload in an oncology outpatient clinic*
}

\author{
MENSURAÇÃO DE CARGA DE TRABALHO DE ENFERMEIROS EM AMBULATÓRIO DE \\ ONCOLOGIA
}

\section{MEDICIÓN DE LA CARGA DE TRABAJO DE LOS ENFERMEROS EN CONSULTORIOS EXTERNOS DE ONCOLOGÍA}

\author{
Célia Alves de Souza ${ }^{1}$, Marli de Carvalho Jericó ${ }^{2}$, Marcia Galan Perroca ${ }^{3}$
}

\begin{abstract}
The growing demand and the degree of patient care in oncological outpatient services, as well as the complexity of treatment have had an impact on the workload of nurses. This study aimed at measuring the workload and productivity of nurses in an oncological outpatient service. An observational study using a work sampling technique was conducted and included seven nurses working in an oncological outpatient service in the south-eastern region of Brazil. A total of 1,487 intervention or activity samples were obtained. Nurses used $43.2 \%$ of their time on indirect care, $33.2 \%$ on direct care, $11.6 \%$ on associated activities, and $12 \%$ on personal activities. Their mean productivity was $88.0 \%$. The findings showed that nurses in this service spend most of their time in indirect care activities. Moreover, the productivity index in this study was above that recommended in the literature.
\end{abstract}

\section{RESUMO}

A crescente demanda, o volume de atendimento ambulatorial em oncologia, assim como a complexidade do tratamento tem causado impacto sobre a carga de trabalho dos enfermeiros. Este estudo teve como objetivos mensurar a carga de trabalho e a produtividade de enfermeiros em um ambulatório de oncologia. Estudo de natureza observacional, utilizando técnica de amostragem de trabalho, foi conduzido em um ambulatório de oncologia na região sudeste do Brasil, tendo como participantes sete enfermeiros. Obteve-se 1.487 amostras de intervenções ou atividades. Observou-se que $43,2 \%$ do tempo dos enfermeiros foi consumido em cuidados indiretos, 33,2\% em cuidados diretos, $11,6 \%$ em atividades associadas e $12 \%$ em atividades pessoais. A produtividade média correspondeu a $88,0 \%$. Os achados permitiram concluir que os enfermeiros do ambulatório de oncologia consumiram a maior parte de seu tempo em atividades de cuidados indiretos. Revelou ainda um índice de produtividade acima dos recomendados na literatura.

\author{
DESCRITORES \\ Enfermagem oncológica \\ Carga de trabalho \\ Ambulatório hospitalar \\ Gerenciamento do tempo \\ Recursos humanos de enfermagem
}

\section{RESUMEN}

La creciente demanda y el volumen de atención en los consultorios externos de oncología, así como la complejidad del tratamiento han causado impacto en la carga de trabajo de los enfermeros. Este estudio tuvo como objetivo medir la carga de trabajo y la productividad de los enfermeros en un consultorio externo de oncología. Estudio observacional, utilizando la técnica de muestreo de trabajo, fue realizado en un servicio de consultorio externo de oncología en la región sur-este de Brasil, donde participaron siete enfermeros. Fueron recolectadas 1.487 muestras de intervenciones o actividades. Se observó que el 43,2\% del tiempo de los enfermeros fue consumido en cuidados indirectos, $33,2 \%$ en cuidados directos, $11,6 \%$ en actividades asociadas y $12,0 \%$ en actividades personales. La productividad promedio correspondió al $88,0 \%$. Los hallazgos permitieron concluir que los enfermeros del servicio de consultorios externos de oncología consumieron la mayor parte de su tiempo en actividades de cuidados indirectos. Reveló, además, un índice de productividad superior a aquellos recomendados en la literatura.

\author{
DESCRIPTORES \\ Enfermería oncológica \\ Carga de trabajo \\ Servicio ambulatorio en hospital \\ Administración del tiempo \\ Personal de enfermería
}

"Extracted from the master dissertation "Measurement of nursing workload of nurses in chemotherapy center", Faculty of Medicine of São José do Rio Preto, 2012. ${ }^{1}$ RN, MSc, Docent, Department of Nursing, Faculty of Medicine of São José do Rio Preto, SP, Brazil. ca.souza1968@hotmail.com ${ }^{2}$ RN, MSc, PhD, Docent, Department of Nursing, Faculty of Medicine of São José do Rio Preto, SP, Brazil. ${ }^{3}$ RN, MSc, PhD, Docent, Department of Nursing, Faculty of Medicine of São José do Rio Preto, SP, Brazil. 


\section{INTRODUCTION}

Malignant neoplasms are a public health problem given their increasing importance as a cause of morbidity and mortality. It is estimated that by 2020 , the annual number of new cases will be 15 million worldwide with approximately $60 \%$ occurring in developing countries ${ }^{(1)}$.

By the end of 2005 in Brazil, there were 251 public services providing high-complexity chemotherapy in oncology registered in the National Health Service (SUS) ${ }^{(2)}$. The costs of these services totaled approximately US $\$ 442,608,439$ (900 Brazilian million reals) for administering 1.6 million chemotherapy procedures, most of which were performed in state and municipal institutions.

São Paulo is the state with the highest population in Brazil and is the third most populous administrative region in South America. It has 76 state and various private institutions for cancer patient care ${ }^{(2)}$. In 2010, 34,690 new cases of cancer were reported in São Paulo State public services and 25,900 chemotherapy sessions were conducted ${ }^{(2)}$.

In recent decades, most of the chemotherapy drug administration has been transferred from the hospital setting to the outpatient clinic $^{(3)}$. According to the National Center for Health Statistics of the United States, 19 of 23 million annual chemotherapy sessions occur in outpatient clinics $^{(4)}$. This higher patient flow combined with treatment complexity has contributed to a significant increase in the workload of nurses ${ }^{(5)}$. Another aspect to be considered is that technological advances of pharmaceutical industries are producing research that aims to increase the efficiency of chemotherapy drugs while decreasing side effects, which requires nurses to have a better understanding of the use of this technology to provide better cancer patient care ${ }^{(6)}$.

\section{Theoretical reference}

Evaluation of the workload of nurses is of fundamental importance in the development of work optimization protocols for nursing professionals. To identify this variable, it is necessary to measure the time that nurses spend to provide both direct and indirect care to patients ${ }^{(7)}$. Assessment of their workload is also used in an attempt to predict the time and skill required to provide care ${ }^{(8)}$. However, measuring the time spent on nursing care in an oncology outpatient clinic is a major challenge because of the unpredictability of the population served ${ }^{(5)}$. Thus, it can be seen that evaluation of the work time of nurses is a factor that determines quality and worker productivity, regardless of what the task is.

The literature describes few instruments to measure the workload of nurses in ambulatory care settings as compared with hospital settings ${ }^{(9)}$. In oncology outpatient clinics, problems related to the planning, allocation, and evaluation of human resources in nursing are greater because of, among other things, the dynamics of the work in the units, the different procedures, and the number of patients ${ }^{(10)}$. Thus, the ambulatory nursing workload is influenced by the complexity of the care (patient classification system), role of nursing (activities), and the number of patients requiring care ${ }^{(9)}$.

Since the 1980s, several studies have been undertaken to analyze the workload of outpatient nursing. One investigation $^{(8)}$ described a process to identify care activities by measuring the time taken by the activities; another study $^{(11)}$ used categorization of chemotherapy drugs as a measure of the time taken for nursing care. An important milestone in the literature occurred with the studies resulting in the classification of outpatient activities as direct care, indirect care, and administrative activities ${ }^{(12)}$.

In the decades that followed, other investigations were conducted on this theme. An instrument to determine the functions and workload of nurses in radiotherapy units and oncology hematology was developed in an Australian study ${ }^{(13)}$ using a work sampling methodology. A prototype scale based on the complexity of oncology outpatient care classified patients into five levels, with care duration varying from less than 30 min to more than $4 h^{(5)}$. A patient classification system that associated chemotherapy drugs with the complexity of care required for their administration categorized the time required into three levels: $I=30$ $\min , \|=60 \mathrm{~min}$, and $\mathrm{II}=90 \mathrm{~min}^{(3)}$.

Although there are international publications that measure time use and workload of nurses in outpatient clinics, in Brazil there are no studies that specifically address this issue in cancer clinics (chemotherapy). Thus, this research aims to evaluate the workload and productivity of nurses working in an oncology outpatient clinic.

\section{METHOD}

This was an observational study using the work sampling technique, i.e., samples of activities were collected at systematic time intervals. With this technique, the total time spent on an activity is inferred on the basis of the percentage of observations related to that activity ${ }^{(14)}$.

This study proposed to answer the following questions: What is the time spent by nurses on activities in an oncology outpatient clinic during the care process? How is time spent distributed between direct care, indirect care, personal activities, and associated activities?

\section{Setting and participants}

This study was conducted in a 130-bed oncology outpatient clinic of a teaching hospital located in the southeastern region of Brazil; this was a referral center for this specialty. The clinic provides care to patients with neoplastic diseases requiring chemotherapy with an average of 3,300 consultations per month and 10,000 drug infusions annually. The multiprofessional team was made up of ten physicians, ten nurses (one supervising
Measurement of nurses' workload in an oncology outpatient clinic Souza CA, Jericó MC, Perroca MG 
nurse), seven nursing technicians, five nursing assistants, and five pharmacists.

Seven nurses who worked in the clinic during the period from March 14, 2011, to March 29, 2011, participated in the study. The professionals were primarily female, had a mean age of 29 years [standard deviation (SD) $=5.7$ years; range $=24-41$ years], had worked as nurses on average for 5.3 years (SD $=4.9$ years; range $=1-14$ years) and in chemotherapy for a mean time of 2.3 years (SD = 1.6 years; range $=1-5$ years). Five of the participants were oncology certified nurses, and the others were studying for certification.

\section{Instrument}

An instrument was created to identify the activities performed by nurses during ambulatory chemotherapy sessions using triangulation of data combining three sources of information: a semi-structured interview, document analysis, and a questionnaire. The activities were categorized according to the standard language of the Nursing Intervention Classification (NIC) ${ }^{(15)}$ and subsequently submitted to content validation ${ }^{(16)}$ to check that the mapped activities were relevant and representative of the health care practice of nurses in chemotherapy cancer clinics.

The adaptation and validation of the instrument occurred in two meetings with the nurses that participated in the study. The objective was to assess the adequacy of the items proposed in the instrument by arriving at a consensus on their relevance and to elucidate doubts related to the designation of some activities. Therefore, interventions/activities that were agreed upon by everyone were considered valid. The validated instrument entailed a list of 35 interventions and 48 nursing activities ${ }^{(17)}$.

Interventions/activities were classified into the following four categories: direct care, indirect care, (according to the $\left.\mathrm{NIC}^{(15)}\right)$, associated work, and personal activities $^{(18)}$. Direct care referred to treatment performed through interactions with the patient, including nursing activities in physiological and psychosocial settings and practical and support measures and counseling about life. Interventions/activities performed at a distance, but for the benefit of the patient, including management of the care setting and interdisciplinary collaboration were named indirect care ${ }^{(15)}$. Associated work encompassed non-nursing activities, i.e., tasks that do not need to be performed by nursing staff, and personal activities were breaks from work for physiological needs and rest $^{(18)}$.

A pilot study using the instrument was conducted to collect 1000 samples during 4 consecutive days, at which time a need to add some extra activities to the list was identified. The final list included 38 interventions and 88 activities, with 70 being categorized as di- rect and indirect care. Observations were performed by two research assistants, nurses who were familiar with the routine of the unit. To verify that the observers understood and recorded activities equally, the reliability of assessment was tested; inter-observer agreement was calculated at $88.5 \%$.

\section{Determination of the sample}

The sample size was statistically determined considering the probability of the occurrence of activities was greater than $0.1 \%$, i.e., $p=1 / 1000$ with a $95 \%$ confidence interval, $\alpha=0.05$, and 10 -min intervals between observations. The average working day in the outpatient clinic lasted $540 \mathrm{~min}$ in addition to a 60 -min meal break. The average number of nurses (five) who worked each day was used to calculate the workflow. Therefore, 3.7 days of observation would be required to obtain 1,080 work activities. To increase the safety margin of the research, the observations were conducted over 5 non-consecutive days.

\section{Identification of the distribution of the nurses' time}

By identifying the proportion of time that the nurses spent on each activity, it was possible to sum the percentages of activities categorized under the same intervention, thereby obtaining the percentage of each intervention. The proportion of time nurses spent on direct care, indirect care, associated work, and personal activities was obtained from the sum of the proportions of time these professionals spent on all interventions/activities.

\section{Ethical aspects}

The study was approved by the Research Ethics Committee of the institution (\# 290/2010), and all participants signed informed consent forms.

\section{Data collection procedure}

The final instrument, after adding the newly identified activities, was employed with the same nurses who were assessed during the pilot study. Each observer accompanied two nurses at a time, for approximately $8 \mathrm{~h}$ a day and made a note of the time of the activities performed using a stopwatch. One of the researchers was present throughout the data collection process to answer any doubts.

\section{Data analysis}

Productivity was calculated from the sum of the proportions of time spent providing direct care, indirect care, and associated work by subtracting the time used for personal activities. The formula used was:

$$
P=(D C+I C+A W)-P A
$$

Where $\mathrm{P}=$ productivity, $\mathrm{DC}=$ direct care, $\mathrm{IC}=$ indirect care, $\mathrm{AW}=$ associated work and $\mathrm{PA}=$ personal activities.

Data are reported as descriptive statistics utilizing the Microsoft Excel program version 2010. 


\section{RESULTS}

A total of 1,890 samples were obtained. Of the 38 interventions originally included, three were not observed during the data collection period and thus excluded. Therefore, the sample comprised 35 interventions and 85 activities. Of the interventions identified, the most common were the exchange of information on health care (12.2\%), documentation (11.5\%), and administration of Endovenous medications (11.1\%), (Figure 1). Indirect care activities accounted for $40.2 \%$ of the total interventions/ activities, and direct care activities for $33.6 \%$.

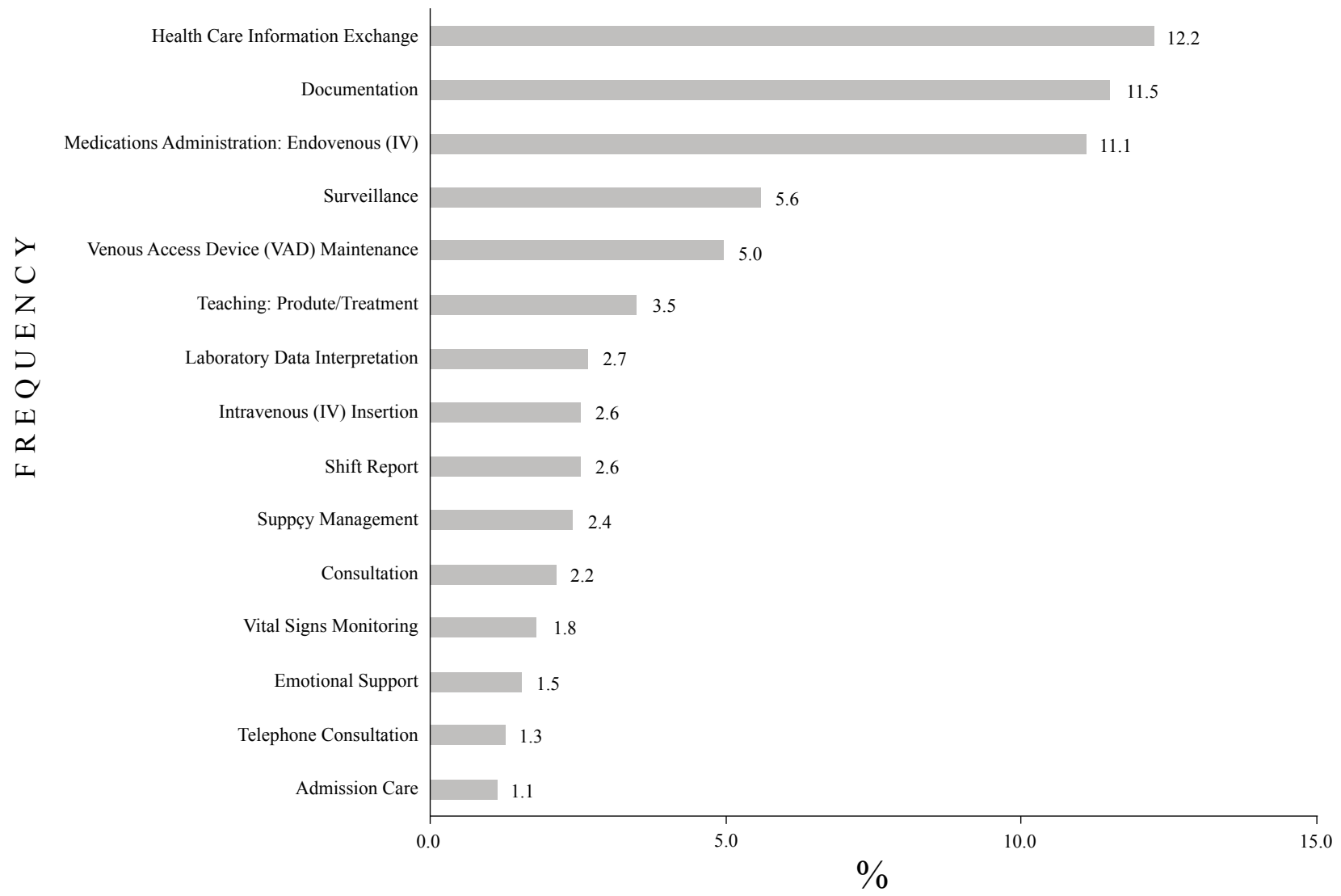

Figure 1 - Mean daily frequencies of the main interventions/activities performed by nurses in an oncology outpatient clinic

Calculation of the mean time for interventions showed that the nurses spent more time on direct and indirect care such as: staff supervision $=27.2 \mathrm{~min}$ (range: 8.1-46.4 $\mathrm{min}$ ), emergency cart checking $=23.3$ min (range: $0.9-45.8 \mathrm{~min}$ ), and consultations $=23.1$ min (range: $17.4-28.8 \mathrm{~min}$ ). Interventions that required less time (an average of $5 \mathrm{~min}$ ) were admission care (range $=4.1-5.9 \mathrm{~min})$; environmental management: comfort (range $=3.9-6.1 \mathrm{~min}$ ); medication administration: oral (range $=2.3-7.7 \mathrm{~min}$ ), transport (range $=$ 2.9-7.1 min), quality monitoring (range = 0.9-9.1 $\mathrm{min}$ ), and consultation by telephone (Chart 1 ). It was not possible to calculate the mean time for five interventions: gastrointestinal intubation, enteral tube feeding, physician support, staff development, and routing and referral because of insufficient samples.

Chart 1 - Mean time of principal interventions performed by nurses in an oncology outpatient clinic - Brazil, 2012

\begin{tabular}{|lllcc|}
\hline Classification & NIC & Nursing interventions/activities & t (min) & 95\% CI \\
\hline & 7910 & Consultation & 23.1 & $17.4-28.8$ \\
& 2240 & Chemotherapy Management & 8.3 & $4.2-12.5$ \\
& 1400 & Pain Management & 8.3 & $4.2-12.5$ \\
& 6200 & Emergency Care & 7.5 & $4.8-10.2$ \\
& 4238 & Phlebotomy: Venous Blood Sample & 7.5 & $4.8-10.2$ \\
Direct Care & 2317 & Subcutaneous Medication Administration & 6.7 & $2.4-11.0$ \\
& 2312 & Intramuscular Medication Administration & 6.5 & $4.3-8.8$ \\
& 2380 & Medication Management & 6.4 & $2.9-9.9$ \\
& 7640 & Critical Path Development & 6.3 & $3.3-9.2$ \\
& 5270 & Emotional Support & 6.3 & $4.8-7.8$ \\
& 4190 & Intravenous (IV) Insertion & 6.3 & $5.0-7.7$ \\
\hline
\end{tabular}




\begin{tabular}{|lclcc|}
\hline ..Continuation & & & \\
\hline Classification & NIC & Nursing interventions/activities & t (min) & 95\% CI \\
\hline & 2314 & Endovenous Medication Administration & 6.2 & $5.6-6.8$ \\
& 2440 & Venous Access Device (VAD) Maintenance & 5.8 & $5.2-6.4$ \\
& 5618 & Teaching: Procedure/Treatment & 5.6 & $4.7-6.4$ \\
Direct Care & 6680 & Vital Signs Monitoring & 5.4 & $4.6-6.1$ \\
& 7310 & Admission Care & 5.0 & $4.1-5.9$ \\
& 6482 & Environmental Management: Comfort & 5.0 & $3.9-6.1$ \\
& 2304 & Oral Medication Administration & 5.0 & $2.3-7.7$ \\
& 960 & Transport & 5.0 & $2.9-7.1$ \\
& 7830 & Staff Supervision & 27.2 & $8.1-46.4$ \\
& 7660 & Emergency Cart Checking & 23.3 & $0.9-45.8$ \\
Indirect Care & 7690 & Laboratory Data Interpretation & 19.0 & $13.0-25.0$ \\
& 7840 & Supply Management & 8.1 & $5.9-10.2$ \\
& 7980 & Incident Reporting & 7.5 & $3.6-11.4$ \\
& 7960 & Health Care Information Exchange & 6.9 & $6.1-7.7$ \\
& 6650 & Surveillance & 6.2 & $5.4-7.0$ \\
& 8140 & Shift Report & 6.1 & $5.0-7.1$ \\
Associated work & 7920 & Documentation & 5.8 & $5.4-6.3$ \\
& 7800 & Quality Monitoring & 5.0 & $0.9-9.1$ \\
& & & 5.0 & $5.0-5.0$ \\
& & & 6.0 & $5.4-6.5$ \\
\end{tabular}

More time was spent by nurses on the different indirect care interventions or activities (43.2\%). Because $12 \%$

of the time of nurses was spent on personal activities, the mean productivity was calculated at $88 \%$ (Table 1 ).

Table 1 - Frequency, time, and percentage of time of interventions/activities performed by nurses in an oncology outpatient clinic Brazil, 2012

\begin{tabular}{lclc}
\hline Intervention/Activity & Quantity & $\mathbf{t}(\mathbf{m i n})$ & $\mathbf{\%}$ \\
\hline Indirect care & 598 & 4610 & 43.2 \\
Direct care & 499 & 3545 & 33.2 \\
Associated & 208 & 1240 & 11.6 \\
Personal & 182 & 1280 & 12.0 \\
Total & 1487 & 10675 & 100 \\
\hline
\end{tabular}

\section{DISCUSSION}

The findings of this study show that the nurses in the oncology outpatient clinic performed more indirect care interventions/activities (40.2\%) and spent more time on these activities (43.2\%). The predominance of time spent on these activities has also been reported by other researchers, e.g., 47.3\% (medical ward)(19), 72.5\% (oncology hematology clinic) ${ }^{(13)}$, and $39.1 \%$ (ambulatory care) ${ }^{(20)}$. However, it is difficult to compare results because these investigations used different methods and classifications.

The indirect care activities that required most time in the oncology clinic were: staff supervision, emergency cart checking, and laboratory data interpretation. The nurses spent 27.2 min on supervision; this is more than the 12.5 min observed in a Brazilian study performed in an emergency unit ${ }^{(7)}$. Many protocols on the infusion of chemotherapy drugs, particularly investigational medicines, require more monitoring by nursing staff to control patients' possible reactions ${ }^{(21)}$. Thus, supervision is essential as a management tool to identify strategies for team cooperation to increase the effectiveness of care.

Emergency cart checking took $23 \mathrm{~min}$ on average. This is part of the daily routine of the nurse who is responsible for providing, organizing and maintaining materials, and equipment for emergency situations ${ }^{(22)}$. It is important to stress that this activity could be delegated to other professionals in the team so that nurses could prioritize their time for value-added activities.

In the oncology outpatient clinic, the role of nurses in interpreting the patients' laboratory data is to prevent or mitigate complications arising from possible adverse effects of chemotherapy drugs ${ }^{(21)}$, including neutropenia, which is indicative of the risk of infection. The interpretation of laboratory results took, on average, $19 \mathrm{~min}$, and this is more than the time used in emergency units $(10 \mathrm{~min})^{(7)}$. It is important to mention that in the outpatient clinic used in this study, nurses have autonomy to decide whether to administer antineoplastic drugs or not, depending on the interpretation of patients' blood results.

Direct care accounted for $33.2 \%$ of the time of nurses, a percentage similar to other studies, i.e., $30 \%$ (surgical ward) ${ }^{(23)}, 35 \%$ (emergency department) ${ }^{(7)}$, and $37 \%$ (ambulatory care $)^{(24)}$. However, other researchers found higher percentages of $44 \%$ in a preventive health unit ${ }^{(25)}$.

The most common interventions/activities performed were not those that demanded the most time from nurses 
such as health care information exchange (12\%, $6.9 \mathrm{~min})$ and documentation (11.5\%, $5.8 \mathrm{~min})$. The direct care interventions/activities that demanded the most time were consultations (23 $\mathrm{min}$ ), chemotherapy management (8.3 $\mathrm{min})$, and pain management ( $8.3 \mathrm{~min}$ ). An estimated time of 30-60 min was reported in a study that included consultations as one activity in a complexity rating system of oncology outpatient clinics $^{(5)}$.

Chemotherapy management was second in the ranking of direct care interventions that demanded the most time from nurses. One activity related to this intervention was informing the patient/family about the mechanism of action of antineoplastic agents. Nurses working in oncology areas play an important role in educating patients about chemotherapy treatment ${ }^{(6)}$. An Australian study performed in an oncology hematology center ${ }^{(13)}$ showed that nurses in the unit needed approximately 13 min per patient for counseling and education.

Pain management is an important factor in the management of cancer-related symptoms. The cancer nurse cares for patients initially by assessing their pain and subsequently by providing information on the best use of medications for pain control ${ }^{(21)}$. The time spent on this intervention in the outpatient clinic for this study was $8.3 \mathrm{~min}$ and thus, similar to another investigation in an emergency room $(10 \mathrm{~min})^{(7)}$.

Personal activities took up $12 \%$ of the shift of nurses, and this was similar to the findings of other researchers who reported $13.5 \%$ (medical ward) ${ }^{(19)}$ and $14 \%$ (outpatient clinic) $^{(24)}$; this was less time compared with the reports of other researchers such as $16 \%$ (Preventive health unit) ${ }^{(25)}$, $18 \%$ (emergency room) $^{(7)}$, and $19.9 \%$ (outpatient clinic) ${ }^{(20)}$.

Associated work corresponded to $11.6 \%$ of the time of the nurses, similar to that in an emergency room $12 \%{ }^{(7)}$, and in other Brazilian publications, this was 7\% (Preventive health unit) ${ }^{(25)}$. These associated work activities included making phone calls, requesting patient records and chemotherapy medications from the pharmacy, and escorting patients to other units.

The reasons why nurses perform activities that could be performed by other professionals have been questioned. Some hypotheses include because nurses feel safer performing

\section{REFERENCES}

1. Word Health Organization. Who global action against cancer. Updated edition, 2005 [Internet]. Geneva; 2005 [cited 2013 July 10]. Available from: http://www.who.int/cancer/media/ en/GlobalActionCancerEnglfull.pdf

2. Fundação Oncocentro de São Paulo. Atendimento oncológico do SUS [Internet]. São Paulo; 2012 [citado 2013 jul. 10]. Disponível em: http://www.fosp.saude.sp.gov.br/epidemiologia/ atendimento_sus.html simpler activities perhaps as a mechanism of escaping from the pressures of caring for patients ${ }^{(26)}$ and because other professionals do not perform the tasks correctly ${ }^{(27)}$. Another reason is related to bureaucratic decisions of health care institutions where the nursing team needs to accept certain responsibilities in response to policies to reduce support services and costs ${ }^{(26)}$. Measurement of the time spent performing associated work enables institutions to review and redesign work processes ${ }^{(23)}$ to minimize the time spent on non-nursing activities ${ }^{(28)}$ and ensuring better collaboration between ancillary team members and the nursing staff. Productivity takes on an important role because it supports decisions related to personnel management and resource allocation ${ }^{(8)}$.

Productivity levels below $80 \%$ indicate a greater likelihood that nurses are satisfied with their work and there is reduced absenteeism ${ }^{(29)}$, while levels above $80 \%$ lead to increased costs and reductions in the quality of care ${ }^{(30)}$. Therefore, these study findings indicate work overload and deserve attention by nursing managers to adopt strategies to ensure the safety of patients and workers alike.

\section{CONCLUSION}

The findings of this study show that nurses in an outpatient oncology clinic (chemotherapy) spent most of their time on indirect care activities. The productivity of these nurses is above that recorded in the literature.

\section{Study limitations}

This study took place in a single institution, thereby making generalization of the findings difficult. In addition, only the mean time and percentage of time spent by nurses in performing interventions/activities were calculated, and this provides only a partial view of the workflow and productivity of the nursing team.

\section{Implications for nursing practice}

The mapping of activities in a standardized language assists in the definition of the role of nursing in the outpatient chemotherapy clinic. This can make the redesigning of work processes, eliminating activities that do not add any value to the customer service, and optimizing productivity possible.
3. Chabot G, Fox M. The creation of a patient-classification system in an outpatient infusion center setting. Oncol Nurs Forum. 2005;32(3):535-8.

4. Kamimura A, Schneider K, Lee CS, Crawford SD, Friese CR. Practice environments of nurses in ambulatory oncology settings: a thematic analysis. Cancer Nurs. 2012;35(1):E1-7.

5. Cusack G, Jones-Wells A, Chisholm L. Patient intensity in an ambulatory oncology research center: a step forward for the field of ambulatory care. Nurs Econ. 2004; 22(2):58-63.
Measurement of nurses' workload in an oncology outpatient clinic Souza CA, Jericó MC, Perroca MG 
6. Quinn A. Expanding the role of the oncology nurse. Biomed Imaging Interv J. 2008;4(3):e34.

7. Garcia EA, Fugulin FMT. Nurses'work time distribution at emergency service. Rev Esc Enferm USP [Internet]. 2010 [cited 2013 July 10];44(4):1032-8. Available from: http://www. scielo.br/pdf/reeusp/v44n4/en_25.pdf

8. Medvec BR. Productivity and workload mensurement in ambulatory oncology. Semin Oncol Nurs. 1994;10(4):288-95.

9. Swan BA, Griffin KF. Measuring nursing workload in ambulatory care. Nurs Econ. 2005;23(5):253-60.

10. DeLisle J. Designing an acuity tool for an ambulatory oncology setting. Clin J Oncol Nurs. 2009;13(1):45-50.

11. Campbell S, Hallgren L, Kamitomo V, Catedral C. Chemotherapy drug administration: a beginning survey of chemotherapy as a workload index. Cancer Nurs. 1984;7(3):213-20.

12. Verran JA. Patient classification in ambulatory care. Nurs Econ. 1986;4(5):247-51.

13. Blay N, Cairns J, Chisholm J, O'Baugh J. Research into the workload and roles of oncology nurses within an outpatient oncology unit. Eur J Oncol Nurs. 2002;6(1):6-12.

14. Finkler SA, Knickman JR, Hendrickson G, Lipkin M Jr, Thompson WG. A comparison of work-sampling and time-andmotion techniques for studies in health services research. Health Serv Res. 1993;28(5):577-97.

15. Dochterman JM, Bulechek GM. Classificação das Intervenções de Enfermagem (NIC). Porto Alegre: Artmed; 2008.

16. Polit DF, Hungler BP, Beck CT. Nursing research: principles and methods. Philadelphia: Lippincott Williams \& Wilkins; 2011. Measurement and data collection; p. 315-37.

17. Souza CA, Perroca MG, Jericó MC. Mapping the nurses interventions and activities in a Chemotherapy Center: a tool for assessing the workload. Rev Latino Am Enferm. 2013;21(2):492-9.

18. Hurst K. Selecting and applying methods for estimating the size and mix of nursing teams: a systematic review of literature commissioned by the Department of Health [Internet]. 2002 [cited 2013 July 10]. Available from: http://www.who. int/hrh/documents/hurst_mainreport.pdf

19. Chaboyer W, Wallis M, Duffield C, Courtney M, Seaton P, Holzhauser $\mathrm{K}$, et al. A comparison of activities undertaken by enrolled and registered nurses on medical wards in Australia: an observational study. Int J Nurs Stud. 2008;45(9):1274-84.
20. Mayer GG. Work sampling in ambulatory care nursing. Nurs Manage. 1992;23(9):52-6.

21. Mick J. Factors affecting the evolution of oncology nursing care. Clin J Oncol Nurs. 2008;12(2):307-13.

22. Gabbott D, Smith G, Mitchell S, Colquhoun M, Nolan J, Soar J, et al.; Royal College of Anaesthetists; Royal College of Physicians of London; Intensive Care Society; Resuscitation Council Cardiopulmonary resuscitation standards for clinical practice and training in the UK. Resuscitation. 2005;64(1):13-9.

23. Upenieks VV. Work sampling: assessing nursing efficiency. Nurs Manage. 1998;29(4):27-9.

24. Urden LD, Roode JL. Work sampling: a decision-making tool for determining resources and work redesign. J Nurs Adm. 1997;27(9):34-41.

25. Bonfim D, Gaidzinski RR, Santos FM, Gonçales CS, Fugulin FMT. The identification of nursing interventions in Primary Health Care: a parameter for personnel staffing. Rev Esc Enferm USP [Internet]. 2012 [cited 2013 July 10];46(6):146270. Available from: http://www.scielo.br/pdf/reeusp/ v46n6/en_25.pdf

26. Wejr P. Non-nursing duties [Internet]. 2010 [cited 2013 July 10]. Available from: http://www.thinknursing.ca/sites/ thinknursing.ca/files/Non_Nursing_Duties.pdf

27. Prescott PA, Phillips CY, Ryan JW, Thompson KO. Changing how nurses spend their time. Image J Nurs Scholarsh. 1991;23(1):23-8.

28. Thompson P, Stanowski A. Maximizing nursing productivity: the benefits of improved collaboration between nursing and support services: building a stronger collaboration between nurses and support services personnel can have positive financial and quality implications for hospitals. Healthc Financ Manage. 2009;63(1):76-85.

29. O' Brien-Pallas L, Thomson D, Hall LM, Pink G, Kerr M, Wang $S$, et al. Evidence-based standards for measuring nurse staffing and performance. Report for the Canadian Health Services Research Foundation, 2003. Otawa: Canadian Health Services Research Foundation; 2004.

30. Herbert N. Provider CON position in improving productivity: a payer provider debate. J Nurs Adm. 1999;29(1):51-6.

\section{Funding source}

Financial support by a Scholarship Assistance Grant to the researcher (BAP), Medicine School in São José do Rio Preto (FAMERP - process no4331/2010). 